\title{
PEMODELAN FAKTOR RISIKO YANG BERHUBUNGAN DENGAN TINGKAT KEPARAHAN PELAKU KECELAKAAN LALU LINTAS DI KABUPATEN TUBAN JAWA TIMUR DENGAN REGRESI LOGISTIK ORDINAL
}

\author{
Atik Agustina \\ Departemen Biostatistika dan Kependudukan \\ Fakultas Kesehatan Masyarakat Universitas Airlangga \\ Jl. Mulyorejo Kampus C Unair Surabaya 60115 \\ E-mail: aagustina66@gmail.com
}

\begin{abstract}
The number of Traffic accident cases is increasing. The impact of traffic accidents not only cause physical harm but also material the amount is not small. The impact of the most minor traffic accident is minor injuries and most fatal is passed. The cause of the severity of this accident also vary. ranging from the human factor, vehicle, to the environment. This study aims to determine what factors influence the severity of traffic accidents.

The experiment was conducted with based on daily data entered in the case of accidents POLRES Tuban. Processing data using SPSS 2.0 with statistic test ordinal logistic regression. Variable used in this study were age, sex, education, occupation, possession of driver's license, the driver factor, the status, the function of roads, location of accident, time of occurrence and type of accident.

Testing simultaneously with ordinal logistic regression to get the result that there are variables that influence the severity. The variable is employment, accident locations, and types of accidents.

The conclusion that can be drawn is the biggest risk of the occurrence of the severity of death occurred in the accident that occurred in the area of the shopping center, while the greatest risk of severe injury severity occur in a single accident types.
\end{abstract}

Keywords: Ordinal Regression, Accident 


\begin{abstract}
ABSTRAK
Kasus kecelakaan lalu lintas dari tahun ke tahun mengalami kenaikan. Dampak dari kecelakaan lalu lintas ini bukan hanya menimbulkan kerugian fisik tetapi juga materiil yang jumlahnya tidak sedikit. Dampak yang paling kecil akibat kecelakaan lalu lintas adalah luka ringan dan yang paling fatal adalah meninggal dunia. Penyebab tingkat keparahan kecelakaan ini juga bermacam-macam. mulai dari faktor manusia, kendaraan, hingga lingkungan. Penelitian ini bertujuan untuk mengetahui faktor apa saja yang berpengaruh terhadap tingkat keparahan kecelakaan lalu lintas.

Penelitian dilaksanakan dengan berdasarkan data harian kasus kecelakaan yang masuk di POLRES Tuban. Pengolahan data menggunakan SPSS 2.0 dengan uji statisti regresi logistik ordinal. Variabel penelitian yang digunakan adalah umur, jenis kelamin, pendidikan, pekerjaan, kepemilikan SIM, faktor pengemudi, status jalan, fungsi jalan, lokasi kecelakaan, waktu kejadian, dan jenis kecelakaan.

Pengujian secara serentak dengan regresi logistik ordinal mendapatkan hasil bahwa ada variabel yang berpengaruh terhadap tingkat keparahan. Variabel tersebut adalah pekerjaan, lokasi kecelakaan, dan jenis kecelakaan.

Kesimpulan yang dapat ditarik adalah risiko terbesar terjadinya keparahan meninggal dunia terjadi pada kecelakaan yang terjadi di kawasan pusat perbelanjaan, sedangkan risiko terbesar keparahan luka berat terjadi pada jenis kecelakaan tunggal.
\end{abstract}

Kata kunci: Regresi Logistik, Kecelakaan

\section{PENDAHULUAN}

Statistika merupakan suatu teknik untuk memperoleh pengetahuan yang teliti dari informasi yang kurang lengkap (Arief, 2008). Seiring perkembangan teknologi saat ini, metode statistika banyak digunakan untuk membantu memecahkan masalah diberbagai bidang, termasuk bidang kesehatan. Salah satu metode statistika yang dapat digunakan adalah regresi.

Regresi merupakan metode statistika untuk mengetahui hubungan antara variabel independen dengan variable dependen (Mifta, 2014). Regresi dibedakan menjadi dua yaitu regresi linier dan regresi non linier. Salah satu metode regresi non linier adalah regresi, dan salah satu metode dari regresi adalah regresi logistik ordinal.

Regresi logistik ordinal adalah perluasan dari regresi logistik biner dimana regresi logistik ordinal merupakan salah satu metode statistika untuk menganalisis data dengan variabel dependen merupakan skala ordinal yang terdiri dari tiga kategori atau lebih dan variabel independen merupakan covariate (jika menggunakan skala interval atau rasio) atau bisa merupakan faktor (jika menggunakan skala nominal atau ordinal), pengujian ini dapat dilakukan secara parsial maupun serentak.
Uji signifikansi parameter model secara serentak dilakukan dengan uji rasio likelihood. Suatu statistik uji rasio likelihood $G$ adalah fungsi dari $\mathrm{L}_{0}$ dan $\mathrm{L}_{1}$ yang berdistribusi $\chi^{2}$ (chi-square) dengan derajat bebas $p$ (banyaknya variabel independen yang ada dalam model) yang didefinisikan sebagai $G=-1\left(L_{o}-L_{1}\right)$ dengan $L_{o}$ adalah log-likelihood dari model tanpa variabel independen, sedangkan $L_{i}$ adalah log-likelihood dari model $p$ variabel independen. Hipotesisnya adalah $\left(\mathrm{H}_{0}\right)=\beta_{k}$ $=0$, untuk semua $k=1,2, \ldots, p$ yang berarti bahwa semua variabel independen tidak signifikan terhadap model dengan daerah penolakan $\mathrm{H}_{0}$ adalah $G>\chi_{(\alpha ; \mathrm{db})}^{2}$ (Hosmer dan Lemeshow 2000).

Uji kesesuaian model (Goodness Of Fit Test) dilakukan untuk mempelajari sejauh mana kecocokan model yang dugunakan. Pengujian tersebut dilakukan dengan menggunakan uji statistik Pearson dan Deviance. Pengujian ini dilakukan untuk mengetahui peranan variabel independen di dalam model yang diuji secara serentak atau bersama-sama (Hosmer dan Lemeshow, 2000).

Hipotesis yang digunakan dalam pengujian tersebut adalah: 
H0 : Model tanpa variabel bebas tertentu adalah model terbaik (model ringkas)

H1 : Model dengan variabel bebas tertentu adalah model terbaik (model lengkap)

Kriteria uji kesesuaian model adalah tolak H0 bila nilai $\mathrm{P}<\alpha$ (Fahmeir, 1994). Uji kesesuaian model juga dapat dijelaskan dengan nilai Pseudo R-Square. Nilai ini mengadopsi nilai koefisien determinasi pada regresi logistik berganda, yang menunjukkan seberapa besar kemampuan variabel independen menjelaskan variabel dependen.

Pemodelan regresi logistik ordinal berdasarkan variabel independen yang signifikan adalah:

$$
\begin{aligned}
\text { Logit } Y 1= & \text { In } Y 11-Y 1=\theta 1+\beta 1 X 1+\beta 2 X 2 \\
& +\cdots+\beta p X p \\
\text { Logit } Y 2 & =\text { In } Y 21-Y 2=\theta 2+\beta 1 X 1+ \\
& \beta 2 X 2+\cdots+\beta p X p
\end{aligned}
$$

Regresi logistik juga menghasilkan rasio peluang (odds ratio) terkait dengan nilai setiap independen. Peluang (odds) dari suatu kejadian diartikan sebagai probabilitas hasil yang muncul yang dibagi dengan probabilitas suatu kejadian tidak terjadi, dan menggambarkan berapa kali risiko terjadi. Secara umum, Odds merupakan perbandingan probabilitas kejadian sukses dengan kejadian tidak sukses dalam suatu kategori (Utomo, 2009).

Berdasarkan syarat yang ada pada regresi logistik ordinal, yang diantaranya adalah skala data pada variabel dependen bersifat ordinal, yaitu mempunyai lebih dari 2 kategori dan setiap kategori dapat diperingkat. Oleh karena itu, uji ini dapat digunakan untuk menguji beberapa permasalahan kasus dengan variabel dependen lebih dari 2 kategori yang bertingkat, seperti tingkat keparahan pelaku kecelakaan lalu lintas.

Indonesia merupakan salah satu negara dengan tingkat kecelakaan yang cukup tinggi. Kecelakaan lalu lintas dinilai menjadi "pembunuh" terbesar ketiga di Indonesia, dibawah penyakit jantung koroner dan tuberculosis/TBC. Sementara itu Organisasi Kesehatan Dunia (WHO) meramalkan pada tahun 2030 kecelakaan lalu lintas akan menjadi faktor pembunuh manusia paling besar kelima di dunia (Media Indonesia, 2011).

Berdasarkan pernyataan Kasubdit Mitra Dikmas Lantas Mabes Polri, AKBP Djuwito Purnomo, bahwa Indonesia menduduki peringkat ke-5 dengan angka kecelakaan tertinggi di Dunia (RRI, 2014). Sedangkan berdasarkan provinsi, seperti yang disampaikan dalam berita KabarPas.com bahwa provinsi jawa timur merupakan provinsi dengan kejadian kecelakaan lalu lintas terbanyak seIndonesia.

Kabupaten Tuban termasuk salah satu wilayah di Jawa Timur dengan jumlah kejadian kecelakaan lalu lintas terbanyak. Jumlah kejadian kecelakaan lalu lintas pada tahun 2015 mencapai 1065 kejadian, dengan rincian 202 orang meninggal dunia, 45 orang luka berat, dan 1407 orang luka ringan. Kerugian materiil akibat kejadian ini sebesar 2,6 miliar. Jumlah ini, menempatkan Kabupaten Tuban sebagai peringkat nomer 2 dengan kasus kecelakaan lalu lintas tertinggi di Jawa Timur. (Samian, 2015).

Penulis membatasi ruang lingkup daerah penelitian yaitu di Kabupaten Tuban Jawa Timur dengan subyek penelitian yakni pelaku kecelakaan. Hal ini karena Pelaku merupakan seseorang yang duduk dibelakang kemudi dan mengemudikan kemudi pada saat kecelakaan.

\section{METODE PENELITIAN}

Data yang digunakan adalah data sekunder yang diperoleh dari Unit Laka Kepolisian Resor Kabupaten Tuban yang tercatat mulai bulan Januari hingga Desember 2015.

Variabel yang digunakan dalam penelitian ini disesuaikan dengan data sekunder yang didapatkan dari Unit Lalu Lintas Kepolisian Resor Kabupaten Tuban mulai bulan Januari hingga Desember 2015.

Variabel dependen (Tingkat Keparahan) dalam penelitian ini dikategorikan menjadi tiga kategori, yaitu: $1=$ Meninggal Dunia

$2=$ Luka Berat

$3=$ Luka Ringan 
Variabel independen yang digunakan pada penelitian ini berdasarkan data yang diperoleh dari Unit Laka Polres Tuban, Jawa Timur. Variabel independen tersebut adalah:

1. Jenis Kelamin

$1=$ Laki-laki

2= Perempuan

2. Pekerjaan

$1=\mathrm{PNS}$

$2=\mathrm{TNI}$

$3=$ POLRI

4=Karyawan Swasta

$5=$ Pelajar

6= Mahasiswa

$7=$ Pengemudi

$8=$ Pedagang

$9=$ Petani/Buruh

10=Lain-Lain

3. Waktu Kejadian

$1=00.00 \mathrm{~s} / \mathrm{d} 06.00$

$2=06.00 \mathrm{~s} / \mathrm{d} 12.00$

$3=12.00 \mathrm{~s} / \mathrm{d} 18.00$

$4=18.00 \mathrm{~s} / \mathrm{d} 00.00$

4. Lokasi Kecelakaan

1=Kawasan Pemukiman

2=Kawasan Pertokoan

3 =Pusat Perbelanjaan

4= Kawasan Wisata

$5=$ Tempat Hiburan

6= Lain-Lain

5. Jenis Kecelakaan

$1=$ Tunggal

$2=$ Depan-Depan

3= Depan Belakang

4= Depan Samping

$5=$ Samping-Samping

$6=$ Beruntun

$7=$ Tabrak Manusia

$8=$ Tabrak Hewan

9=Lain-Lain (Penumpang Jatuh, dll)

Langkah analisis yang dilakukan dalam penelitian ini dimulai dengan melakukan analisis statistik deskriptif. Selanjutnya melakukan pengujian secara serentak menggunakan regresi logistik ordinal dari variabel independen terhadap variabel dependen. Kemudian dilakukan uji kesesuaian model. Ini dilakukan untuk mengetahui apakah model layak untuk digunakan. setelah itu, dilakukan pengujian variabel independen secara serentak untuk mengetahui variabel yang berpengaruh secara signifikan. Dari variabel yang signifikan tersebut dibuat pemodelan. Selanjutnya pengujian odds ratio dengan regresi logistik ganda untuk mengetahui besarnya pengaruh variabel independen terhadap variabel dependen. Tahap yang terakhir adalah menginterpretasikan dari hasil pengujian yang didapat.

\section{HASIL DAN PEMBAHASAN}

Data yang diperoleh sebanyak 555 data pelaku kecelakaan lalu lintas dari bulan januari hingga desember 2015. Berdasarkan data tersebut, sebanyak $19,6 \%$ pelaku kecelakaan meninggal dunia, 6,1\% luka berat, dan 74,2\% mengalami luka ringan.

Tabel.1. Distribusi Pelaku Kecelakaan Lalu Lintas

\begin{tabular}{|c|c|c|}
\hline \multicolumn{3}{|l|}{ Variabel } \\
\hline Jenis Kelamin & & \\
\hline Laki-laki & 460 & $82.9 \%$ \\
\hline Perempuan & 95 & $17.1 \%$ \\
\hline Pekerjaan & & \\
\hline Pelajar & 14 & $2.5 \%$ \\
\hline Karyawan & & \\
\hline Swasta & 3 & $.5 \%$ \\
\hline Mahasiswa & 419 & $75.5 \%$ \\
\hline Pedagang & 72 & $13.0 \%$ \\
\hline PNS & 18 & $3.2 \%$ \\
\hline Petani/Buruh & 11 & $2.0 \%$ \\
\hline Lokasi & & \\
\hline Kecelakaan & & \\
\hline TNI & 15 & $2.7 \%$ \\
\hline Lain-lain & 3 & $.5 \%$ \\
\hline Kawasan & & 8270 \\
\hline Pemukiman & 459 & $82.7 \%$ \\
\hline $\begin{array}{l}\text { Kawasan } \\
\text { Pertokoan }\end{array}$ & 7 & $1.3 \%$ \\
\hline Jenis & & \\
\hline Kecelakaan & & \\
\hline $\begin{array}{l}\text { Pusat } \\
\text { Perbelanjaan }\end{array}$ & 4 & $.7 \%$ \\
\hline Kawasan & 6 & $110 \%$ \\
\hline Hiburan & 6 & $1.1 \%$ \\
\hline Lain-lain & 79 & $14.2 \%$ \\
\hline Tungga; & 30 & $5.4 \%$ \\
\hline Depan Depan & 116 & $20.9 \%$ \\
\hline $\begin{array}{l}\text { Depan } \\
\text { Belakang }\end{array}$ & 119 & $21.4 \%$ \\
\hline $\begin{array}{l}\text { Depan } \\
\text { Samning }\end{array}$ & 183 & $33.0 \%$ \\
\hline
\end{tabular}




$\begin{array}{lll}\text { Samping } & 71 & 12.8 \% \\ \text { Samping } & & \\ \text { Tabrak } & 36 & 6.5 \% \\ \text { Manusia } & 3\end{array}$

Analisis regresi logistik ordinal dengan 6 variabel independen yang diamati dalam penelitian diuji secara serentak dengan memasukkan semua variabel. Pada tahap pengujian ini diperoleh hasil apakah variabel independen yang digunakan memiliki pengaruh terhadap variabel dependen. Hipotesis yang digunakan pada pengujian ini yaitu:

$\mathrm{H} 0: \beta 1=\beta 2=\ldots=\beta \mathrm{k}=0$

Artinya adalah Tidak ada pengaruh variabel independen terhadap variabel dependen

H1 : minimal ada satu $\beta \neq 0$

Artinya adalah Minimal ada satu variabel independen yang berpengaruh terhadap variabel dependen

Tabel 2. Hasil uji Likelihood Ratio

\begin{tabular}{lrrr}
\hline & $X^{2}$ & df & Sig. \\
\hline Final & 39.069 & 19 & .004
\end{tabular}

Berdasarkan tabel 2, dapat dilihat bahwa nilai $\mathrm{P}$ adalah 0,004 . Maka dengan menggunakan $\alpha$ sebesar 0,05 dimana nilai ini lebih besar dari nilai $\mathrm{P}=0,004$ maka $\mathrm{H} 0$ ditolak, yang berti bahwa minimal ada satu variabel independen yang berpengaruh terhadap variabel dependen.

Selanjutnya dilakukan uji kesesuaian model. Hasil dari pengujian tersbeut dapat dilihat pada tabel 3 .

Tabel 3. Uji Kesesuaian Model (Goodness of Fit)

\begin{tabular}{|c|c|c|c|}
\hline & $\begin{array}{l}\text { Chi- } \\
\text { Square }\end{array}$ & $\mathrm{df}$ & $\begin{array}{c}\text { P- } \\
\text { Value }\end{array}$ \\
\hline Pearson & 646.135 & 583 & 0.036 \\
\hline Deviance & 464.957 & 583 & 1.000 \\
\hline & $\begin{array}{l}\text { Ketepatan } \\
\text { lasifikasi }\end{array}$ & \multicolumn{2}{|c|}{0.90} \\
\hline
\end{tabular}

Uji kesesuaian model ini dilakukan untuk mengetahui peranan variabel independen di dalam model yang diuji secara serentak atau bersama-sama (Hosmer dan Lemeshow, 2000). Hasil dari uji kesesuaian model ini dapat dilihat pada tabel 3 dilihat bahwa pengujian dengan statistik korelasi Pearson menghasilkan nilai $\mathrm{P}=0,036$ dan Deviance dengan nilai $\mathrm{P}$ $=1,000$. Kriteria uji kesesuaian model adalah tolak $\mathrm{H} 0$ bila nilai $\mathrm{P}<\alpha$ (Fahmeir, 1994). Hal ini berarti H0 diterima karena nilai $\mathrm{P}$ (Deviance) $>\alpha$. Sehingga dapat disimpulkan bahwa model tanpa variabel independen tertentu adalah model yang terbaik dan model logit yang didapat layak untuk digunakan.

Tabel 3 juga didapatkan ketepatan klasifikasi. Nilai ketepatan klasifikasi ini mennggambarkan seberapa besar variabel independen menjelaskan variabel dependen. Nilai pada tabel 3 diperoleh ketepatan klasifikasi sebesar 0.90, ini berarti bahwa variabel independen dapat menjelaskan variabel tingkat keparahan pelaku kecelakaan sebesar $90 \%$.

Tabel 4.

\begin{tabular}{|c|c|c|c|}
\hline & Koef. & $\begin{array}{l}\text { Standar } \\
\text { Eror }\end{array}$ & $\begin{array}{c}\mathrm{P} \\
\text { Valu } \\
\mathrm{e}\end{array}$ \\
\hline \multicolumn{4}{|l|}{ Tingkat } \\
\hline \multicolumn{4}{|l|}{ Keparahan } \\
\hline \multicolumn{4}{|l|}{ Meninggal } \\
\hline Dunia & $\begin{array}{r}19.67 \\
6\end{array}$ & $\begin{array}{r}392.83 \\
3\end{array}$ & .000 \\
\hline \multirow[t]{2}{*}{ Luka Berat } & - & 379.31 & \\
\hline & $\begin{array}{r}19.30 \\
1\end{array}$ & 1 & .000 \\
\hline Umur & .046 & .333 & .564 \\
\hline $\begin{array}{l}\text { Waktu } \\
\text { Kejadian }\end{array}$ & -.139 & 1.493 & .222 \\
\hline \multicolumn{3}{|l|}{ Jenis } & \\
\hline Perempuan & -.229 & .623 & .430 \\
\hline \multicolumn{4}{|l|}{ Pekerjaan } \\
\hline PNS & $\begin{array}{r}- \\
17.13 \\
9\end{array}$ & $\begin{array}{r}374.85 \\
9\end{array}$ & .000 \\
\hline POLRI & .136 & .000 & 1.000 \\
\hline Karyawan & - & & \\
\hline Swasta & $\begin{array}{r}17.12 \\
6\end{array}$ & $\begin{array}{r}004.09 \\
4\end{array}$ & .000 \\
\hline Pelajar & $\begin{array}{r}- \\
16.34 \\
8\end{array}$ & $\begin{array}{r}528.82 \\
2\end{array}$ & .000 \\
\hline
\end{tabular}




\begin{tabular}{|c|c|c|c|}
\hline Mahasiswa & 18.15 & $\begin{array}{r}524.43 \\
1\end{array}$ & .000 \\
\hline Pengemudi & $\begin{array}{r}- \\
17.57 \\
2\end{array}$ & $\begin{array}{r}403.89 \\
3 \\
\end{array}$ & .000 \\
\hline Lokasi & & & \\
\hline Kecelakaan & & & \\
\hline $\begin{array}{l}\text { Kaw. } \\
\text { Pemukiman } \\
\text { Pusat }\end{array}$ & -.135 & .023 & .879 \\
\hline $\begin{array}{l}\text { Perbelanjaa } \\
\mathrm{n}\end{array}$ & -2.482 & 4.515 & .034 \\
\hline $\begin{array}{l}\text { Kaw. } \\
\text { Pertokoan }\end{array}$ & -1.288 & 2.289 & .130 \\
\hline Jenis & & & \\
\hline Kecelakaan & & & \\
\hline Tunggal & -1.526 & 5.855 & .016 \\
\hline $\begin{array}{l}\text { Depan- } \\
\text { Depan }\end{array}$ & -1.431 & 6.964 & .008 \\
\hline $\begin{array}{l}\text { Depan } \\
\text { Belakang }\end{array}$ & -.807 & 2.167 & .141 \\
\hline $\begin{array}{l}\text { Depan } \\
\text { Samping }\end{array}$ & -.812 & 2.284 & .131 \\
\hline $\begin{array}{l}\text { Samping- } \\
\text { samping }\end{array}$ & -.733 & 1.593 & .207 \\
\hline
\end{tabular}

Sebuah variabel dikatakan berpengaruh signifikan bila nilai $\mathrm{P}<\alpha$ $(0,05)$ sedangkan untuk variabel sisanya dapat dikatakan tidak berpengaruh signifikan terhadap variabel dependen (Fahmier, 1994). Pengujian parameter dengan regresi logistik ordinal secara serentak didapatkan hasil 3 variabel dari 6 variabel independen signifikan terhadap variabel dependen. Variabel tersebut antara lain lokasi kecelakaan, pekerjaan, dan jenis kecelakaan.

Hasil penelitian ini sesuai dengan penelitian yang dilakukan oleh Wahyu, dkk (2012) yang meneliti tentang "Faktor-faktor yang Mempengaruhi Keparahan Korban Kecelakaan Lalu Lintas di Kota Surabaya dengan Pendekatan Bagging Regresi Logistik Ordinal". Penelitian tersebut mendapatkan hasil bahwa faktor yang mempengaruhi keparahan korban kecelakaan lalu lintas di kota Surabaya adalah jenis kecelakaan, peran (profesi), lokasi kecelakaan, kendaraan lawan, dan usia.
Berdasarkan hasil pengujian secara serentak, maka model regresi logistik ordinal yang diperoleh adalah sebagai berikut:

Y1 (Meninggal Dunia) $=-19,676-17,139$ (PNS) - 17,126 (Karyawan Swasta) 16,348 (Pelajar) - 18,153 (Mahasiswa) - 17,572 (Pengemudi) - 2,482 (Pusat Perbelanjaan) - 1,526 (Tunggal) - 1,431 (Depan-Depan)

Y2 $($ Luka Berat $)=-19,301-17,139(\mathrm{PNS})$ - 17,126 (Karyawan Swasta) - 16,348 (Pelajar) - 18,153 (Mahasiswa) 17,572 (Pengemudi) - 2,482 (Pusat Perbelanjaan) - 1,526 (Tunggal) - 1,431 (Depan-Depan)

Tabel 5. Odds Ratio

\begin{tabular}{|c|c|}
\hline \multirow[b]{2}{*}{ Sub Variabel } & Odds Ratio \\
\hline & $\begin{array}{l}\text { Meninggal Luka Berat } \\
\text { Dunia }\end{array}$ \\
\hline Pekerjaan & 1.058 \\
\hline $\begin{array}{l}\text { Lokasi } \\
\text { Kecelakaan }\end{array}$ & 0.085 \\
\hline Jenis Kecelakaan & 0.807 \\
\hline \begin{tabular}{l}
\multicolumn{2}{c}{ Setelah di } \\
parameter secara \\
selanjutnya adalah $n$ \\
dengan menggunak: \\
berganda (multinom \\
besarnya pengarı \\
kecelakaan, profesi, \\
dapat diinterpretasik \\
Ratio (OR) (Hosmer \\
Odds ratio meru \\
probabilitas kejad \\
kejadian tidak sukse \\
(Utomo, 2009). \\
Odds ratio yan \\
pada odds ratio var \\
secara signifikan \\
variabel dependen b \\
Variabel-variabel \\
Pekerjaan (PNS, Kar \\
Mahasiswa, dan \\
Kecelakaan (Kawasa \\
dan Jenis Kecelakaar \\
Depan).
\end{tabular} & $\begin{array}{l}\text { akukan pengujian } \\
\text { serentak, langkah } \\
\text { encari nilai odds ratio } \\
\text { n uji regresi logistik } \\
\text { al) untuk mengetahui } \\
\text { h variabel jenis } \\
\text { dan lokasi kecelakaan } \\
\text { an dengan nilai Odds } \\
\text { dan Lemeshow, 2000). } \\
\text { pakan perbandingan } \\
\text { an sukses dengan } \\
\text { dalam suatu kategori } \\
\text { g digunakan ini hanya } \\
\text { abel independen yang } \\
\text { erpengaruh terhadap } \\
\text { serta sub variabelnya. } \\
\text { ersebut antara lain } \\
\text { yawan Swasta, Pelajar, } \\
\text { Pengemudi), Lokasi } \\
\text { n Pusat Perbelanjaan), } \\
\text { (Tunggal, dan Depan- }\end{array}$ \\
\hline
\end{tabular}


Berdasarkan tabel 5, maka hasil odds ratio dapat diinterpretasikan sebagai berikut:

Odds ratio Pekerjaan (Meninggal Dunia) sebesar 1.05 artinya adalah dengan pekerjaan pelaku kecelakaan yang terdiri dari PNS, Karyawan Swasta, Pelajar, Mahasiswa, dan Pengemudi memiliki risiko 1.05 kali mengalami tingkat keparahan kecelakaan meninggal dunia. Sama halnya dengan risiko untuk mengalami luka berat, yaitu sebesar 1.05 kali.

Odds ratio Lokasi Kecelakaan (meninggal dunia) sebesar 0.085 artinya adalah pelaku yang mengalami kecelakaan lalu lintas di kawasan pusat perbelanjaan memiliki risiko meninggal dunia sebesar 0.085 kali. Sedangkan Pelaku yang berisiko luka berat sebesar 1.11 kali.

Odds ratio Jenis Kecelakaan (meninggal dunia) sebesar 0,79 artinya Pelaku yang mengalami kecelakaan lalu lintas tabrak depan depan dan kecelakaan lalu lintas tunggal memiliki risiko meninggal dunia sebesar 0.79 kali. Sedangkan Pelaku yang berisiko mengalami luka berat sebesar 0.80 kali.

\section{SIMPULAN DAN SARAN}

Pada pemodelan regresi logistik ordinal yang dilakukan pengujian secara serentak didapatkan bahwa variabel independen yang mempengaruhi variabel respon adalah Profesi (PNS, Karyawan Swasta, Pelajar, Mahasiswa, dan Pengemudi), Lokasi Kecelakaan (Kawasan Pusat Perbelanjaan), dan Jenis Kecelakaan (Kecelakaan Tunggal dan Tabrak Depan depan). Model regresi logistik yang didapatkan adalah:

Y1 $($ Meninggal Dunia $)=-19,676-17,139$ (PNS) - 17,126 (Karyawan Swasta) 16,348 (Pelajar) - 18,153 (Mahasiswa) - 17,572 (Pengemudi) - 2,482 (Pusat Perbelanjaan) - 1,526 (Tunggal) - 1,431 (Depan-Depan)

Y2 $($ Luka Berat) $=-19,301-17,139$ (PNS)
- 17,126 (Karyawan Swasta) - 16,348
(Pelajar) - 18,153 (Mahasiswa) -
17,572 (Pengemudi) - 2,482 (Pusat
Perbelanjaan) - 1,526 (Tunggal) - 1,431 (Depan-Depan)

Saran yang dapat diberikan berdasar penelitian ini pada peneliti selanjutnya disarakan untuk menggunakan kasus data yang lebih bervariatif dan data kualitatif dan kuantitatif pada variabel independen agar menghasilkan nilai standard eror yang lebih besar.

\section{DAFTAR PUSTAKA}

Afidah, Laylia Nur., Susilaningrum, Destri., 2011. Pola Tingkat Keparahan Korban Kecelakaan Lalu Lintas Dengan Menggunakan Regresi Logistik Multinomial (Studi Kasus: Kecelakaan Lalu Lintas Di Surabaya). Jurnal Statistika. Fakultas MIPA Institut Teknologi Sepuluh Nopember (ITS) Surabaya.

Agresti, A., (2007), An Introduction to Categorical Data Analysis Second Edition, John Willey \& Sons, Inc, Canada.

Albana, Majid., 2013. Aplikasi Regresi Logistik Ordinal Untuk Menganalisa Tingkat Kepuasan Pengguna Jasa Terhadap Pelayanan di Stasiun Kota Jakarta. Skripsi. Bogor. Fakultas Matematika dan Pengetahuan Alam Universitas Pakuwan.

Alfiani, Mifta Luthfin., Indah Manfaati.,

Tiani Wahyu., 2014. Model Regresi Nonparametrik Berdasarkan Estimator Polinomial Lokal Kernel Pada Kasus Pertumbuhan Balita. Jurnal Statistika, Vol. 2, No. 1. Semarang. Fakultas MIPA Universitas Muhammadiyah Semarang.

Anwar, Rosihan., 2014. Indonesia Peringkat Lima Dunia Tingkat Kecelakaan Lalu Lintas. [Diakses tanggal 8 November 2014] http://rri.co.id.

Depkes RI (2009). Profil Kesehatan Indonesia. Jakarta: Depertemen Republik Indonesia. 
Elok, Megahardiyani Citra., Susilaningrum Destri., 2009., Analisis Regresi Logistik Ordinal Untuk Mengetahui Faktor-Faktor Yang Mempengaruhi Status Gizi Balita Nelayan Kecamatan Bulak Surabaya. Jurnal Statistika. Fakultas MIPA Institut Teknologi Sepuluh November Surabaya.

Fattah, Imam Ahmad Al., 2013. Analisis

Faktor-faktor yang Mempengaruhi

Masa Studi Lulusan Mahasiwa Program Magister Institut

Teknologi Sepuluh Nopember (ITS) Surabaya Menggunakan Regresi Logistik Ordinal Dan Regresi Probit Ordinal. Jurnal Statistika. Fakultas MIPA Institut Teknologi Sepuluh November Surabaya.

Gatra., 2013. Paparan Akhir Tahun 2013.

[Diakses pada 18 November 2015]. http://www.gatra.com.

Haloho, O., Sembiring P., 2013. Penerapan

Analisis Regresi Logistik pada Pemakaian Alat Kontrasepsi Wanita. Jurnal Universitas Sumatera Utara, 1(1): pp.51-61.

Hosmer, D.W. dan Lemeshow, S., 2000. Applied Logistic Regression, John Wiley and Sons, New York.

Imawati, Aulia., Kismanto Arie., 2011. Analisis Regresi Logistik Biner Pada Faktor-Faktor Yang Mempengaruhi Wanita Menikah Muda Di Provinsi Jawa Timur. Jurnal Statistika. Fakultas MIPA Institut Teknologi Sepuluh November Surabaya.

Imaslihkah, Sitti., dkk., 2013. Analisis Regresi Logistik Ordinal terhadap Faktor-faktor yang Mempengaruhi Predikat Kelulusan Mahasiswa S1 di ITS Surabaya. Jurnal Statistika. Fakultas MIPA Institut Teknologi Sepuluh November Surabaya.

Irjen Pol. Drs. Pudji Hartanto, MM. Jadilah Pelopor Keselamatan Berlalu lintas dan Budayakan Keselamatan sebagai Kebutuhan. Jakarta. Korlantas Mabes Polri, 2012. Hal. 2.
Kartika, M., 2009. Analisis Faktor-Faktor Penyebab Kecelakaan Lalu Lintas Pada Pengendara Sepeda Motor Di Wilayah Depok Tahun 2008. Skripsi. Fakultas kesehatan masyarakat. Universitas Indonesia Jakarta.

Latifah, Tholiatul., 2015. Pemodelan Tingkat Pemakaian Listrik Rumah Tangga Dengan Pendekatan Regresi Logistik Ordinal. Skripsi. Fakultas Sains dan Teknologi, Universitas Airlangga Surabaya.

Media Indonesia 2011. Pemerintah Luncurkan Aksi Keselamatan Jalan [Diakses pada 9 April 2016)].:http://www.mediaindonesi a.com $/ \mathrm{read} / 2011 / 06 / 17 / 234834 / 35$ /5/Pemerintah-Luncurkan-AksiKeselamatan-Jalan.

Putri, Cahaya Eka., 2014. Analisis Karakteristik Kecelakaan Dan Faktor Penyebab Kecelakaan Pada Lokasi Blackspot Di Kota Kayu Agung. Jurnal Teknik. Fakultas Teknik Institut Teknologi Sepuluh November Surabaya.

Rosyida, L., Daryono Prasetyo, Ketut Suharsono., 2015. Kajian Kecelakaan Lalu Lintas Di Jalan Arteri Pada Jalur Pantura Wilayah Tuban. Skripsi. Fakultas Ilmu Sosiologi Universitas Surabaya.

Sagita, Insharie Arie., 2005. Perbandingan Hasil Analisis Regresi Ordinal dan Regresi Logistik Multinomial untuk Mengetahui Faktor yang Mempengaruhi Tingkat Fertilitas Wanita Usia Subur yang Berstatus Pernah Kawin di Kabupaten Bangkalan. Skripsi. FKM Universitas Airlangga.

Samian., 2015. Tuban Peringkat Dua Laka Lantas. [Diakses Tanggal 9 November 2015]. http://suarabanyuurip.com.

Suwandi., 2015. Kecelakaan Lantas di Tuban Tinggi, Komisi D DPRD Jatim Minta Evaluasi.[ Diakses tanggal 8 November 2015]. http://www.bangsaonline.com. 
Syazali, Muhammad., 2014. Analisis Regresi Ordinal. Jurnal Statistika. Fakultas MIPA Universitas Mulawarman Samarinda.

Utomo, S., 2009. Model Regresi Logistik untuk Menunjukkan Pengaruh Pendapatan per Kapita, Tingkat Pendidikan, dan Status Pekerjaan terhadap Status Gizi Masyarakat Kota Surakarta. Skripsi. Universitas Sebelas Maret.

Wibowo, Arief., 2008. Catatan Kuliah Biostatistika Non Parametrik. Surabaya: FKM Unair. 
JURNAL ILMIAH KESEHATAN MEDIAHUSADA ｜ VOLUME 05/NOMOR 02/OKTOBER 2016 